\title{
HOLOCENE HIGH FLOODS ON THE PLANINA POLJE, CLASSICAL DINARIC KARST, SLOVENIA
}

\author{
VISOKE POPLAVE V HOLOCENU NA PLANINSKEM POLJU, \\ KLASIČNI DINARSKI KRAS, SLOVENIJA
}

\author{
Uroš STEPIŠNIK ${ }^{1}$, Mateja FERK ${ }^{2}$, Petra GOSTINČAR ${ }^{3} \&$ Luka ČERNUTA $^{4}$
}

\begin{abstract}
UDC 911.2:556.166(497.471Planinsko polje) 556.166:551.435.8(497.471Planinsko polje)

Uroš Stepišnik, Mateja Ferk, Petra Gostinčar \& Luka Černuta: Holocene high floods on the Planina Polje, Classical Dinaric Karst, Slovenia

The Planina Polje is located in the northwestern part of Notranjsko Podolje, Slovenia. Annual floods cover the flattened floor of the polje at elevation $445 \mathrm{~m}$ a.s.l. and reach the depth of approximately 8 meters. Loamy sediments which were found on surface and subsurface features from the inflow part of Planina Polje up to the elevations of about $495 \mathrm{~m}$ a.s.l., indirectly show that floods in the past must have been much more extensive than the recent ones. Radiocarbon dating of flowstone layer from side passage Tiha Jama in Planina Cave revealed that the last such extreme floods appeared around 5,706 \pm 49 BP. The time frame of the flood roughly corresponds with the Altithermal (8,000-5,000 BP). More humid mid-Holocene climate might be the main cause for the high floods on Planina Polje. Keywords: geomorphology, floods, radiocarbon dating $\left({ }^{14} \mathrm{C}\right)$, Dinaric Karst, Planina Polje, Planina Cave.
\end{abstract}

Izvleček UDK 911.2:556.166(497.471Planinsko polje) 556.166:551.435.8(497.471Planinsko polje)

Uroš Stepišnik, Mateja Ferk, Petra Gostinčar \& Luka Černuta: Visoke poplave v holocenu na Planinskem polju, klasični Dinarski kras, Slovenija

Planinsko polje je kraško polje, ki leži v severozahodnem delu Notranjskega podolja v Sloveniji. Vsakoletne poplavne vode poplavijo celotno uravnano dno polja na nadmorski višini $445 \mathrm{~m}$ in dosežejo globino približno 8 metrov. Ilovnati sedimenti na površju in $\mathrm{v}$ jamah na pritočni strani Planinskega polja, najdeni do okoli $495 \mathrm{~m}$ n. v., posredno kažejo, da so bile poplave v preteklosti veliko bolj obsežne kot današnje. Radiokarbonsko datiranje plasti sige iz stranskega rova Tiha Jama v Planinski jami je pokazalo, da so bile zadnje ekstremne poplave v času okoli $5.706 \pm 49$ BP. Časovni okvir poplav približno ustreza obdobju altitermala (8.000-5.000 BP). Vlažno podnebje srednjega holocena bi lahko bil tudi glavni razlog za visoke poplave na Planinskem polju.

Ključne besede: geomorfologija, poplave, radiokarbonsko datiranje $\left({ }^{14} \mathrm{C}\right)$, Dinarski kras, Planinsko polje, Planinska jama.

\section{INTRODUCTION}

Planina Polje (Planinsko polje) is one of the karst poljes on Classical Karst in Slovenia which is a part of the Dinaric Karst. It is situated in the northwestern part of Notranjsko Podolje and represents the most important confluence of karst waters in the basin of the Ljubljanica River (Cerkniško Polje, the Pivka Basin, and the Javorni- ki Mts.). Due to its morphological and hydrological characteristics it is defined as the most typical karst polje in Slovenia (Gams 2004). During floods the water covers the whole floor of polje, forming a lake of approximate 8 meters in depth (Gospodarič \& Habič 1976).

\footnotetext{
${ }^{1}$ Faculty of Arts, Department of Geography, Aškerčeva 2, SI-1000 Ljubljana, Slovenia, e-mail: uros.stepisnik@gmail.com

${ }^{2}$ Anton Melik Geographical Institute ZRC SAZU, Gosposka ulica 13, SI-1000 Ljubljana, Slovenia, e-mail: mateja.ferk@zrc-sazu.si

${ }^{3}$ Karst Research Institute ZRC SAZU, Titov trg 2, SI-6230 Postojna, e-mail: petra.gostincar@zrc-sazu.si

${ }^{4}$ Brdo 70, SI-5230 Bovec, Slovenia, e-mail: crni.lukc@gmail.com
}

Received/Prejeto: 17.5.2010 
Detailed investigations of the inflow part of Planina Polje and the caves in the hinterland revealed that the early Holocene floods reached much higher elevations than recent floods do. The aim of this study was to re- construct the extent, sedimentation mechanisms and time incidence of extreme Holocene floods on Planina Polje. The study is a contribution to the understanding of morphology and hydrology of the polje.

\section{METHODOLOGY}

In order to acquire data about the occurrence and extent of floods at higher elevations, an extensive research was carried out. The investigation based on detailed geomorphological mapping and morphometric analyses in the hinterland of the inflow part of Planina Polje. Furthermore, detailed speleological analyses of the caves from the inflow part of the polje were conducted. Sediment and flowstone were sampled from selected surface karst features and caves. The mechanism of sedimentation and the origin of loamy sediment were established in the laboratory with grain-size and petrographic analyses. Petrographic analysis of sandy fractions was performed in order to determine the origin of the loamy sediment.

Extent and volume of high floods were established with GIS using Golden Software Surfer 9. Digital elevation model (DEM) with cells $12.5 \mathrm{~m}$ was used.

The approximate age of the sedimentation was established with Radiocarbon dating of flowstone from the
Tiha Jama which is a side passage of the Planina Cave. The dating analysis was performed with radioactive isotope ${ }^{14} \mathrm{C}$ in the Laboratory for Measurements of Low-level Radioactivity at the Ruđer Bošković Institute, Zagreb, Croatia.

Subsurface structure of loamy sediment fills in selected surface karst features were established with the use of Electrical resistivity imaging (ERI) and the interpretation of output data. The SuperSting R1/IP earth resistivity meter (Advanced Geosciences, Inc.) was used for data collection. The survey was conducted with the dipole-dipole array with $5 \mathrm{~m}$ spacing between two electrode pairs. The data were processed to generate twodimensional resistivity models using EarthImager 2D resistivity inversion software.

\section{REGIONAL SETTING}

Planina Polje is situated on the Classical Karst between Postojna and Vrhnika. The Unica River, which flows across Planina Polje, is a part of the Ljubljanica River catchment. The catchment area of the Unica River is about $800 \mathrm{~km}^{2}$ (Žibrik et al. 1976). The river drains allogenic catchment which includes a series of karst poljes in the Notranjsko Podolje and its surroundings. It also receives some autogenic recharge from the higher areas of Snežnik and Javorniki (Žibrik et al. 1976).

Planina Polje is elongated in northwest-southeast direction and covers an area of over $10 \mathrm{~km}^{2}$. The rim of the polje is closed and in the lowest part it is about $55 \mathrm{~m}$ above the flattened floor which is on elevation between 445 and $450 \mathrm{~m}$. The floor is almost uniformly flat with some small-scale irregularities represented by various surface karst features (Ravnik 1976) which are up to two meters high. On the southern rim of the polje there are two pocket valleys where the permanent springs of the Unica River and the Malenščica
River emerge. The waters from the two springs join together into the Unica River. Nearby there is Škratovka, a group of intermittent karst springs. In the northern and northeastern part of the polje the water sinks in numerous ponors and also two small blind valleys are formed (Fig. 1).

Planina Polje lies within lowered karst surface of Idrija strike-slip fault zone. Its geometry seems is strongly influenced by geological structures (Vrabec 1994). Planina Polje is situated mostly in fractured Upper Triassic and Lower Jurassic dolomite (Fig. 1). The northern, northeastern and inflow part in the south are stratigraphically positioned in Lower and Middle Cretaceous limestones (Buser et al. 1970). Tectonically deformed dolomite underlying sedimentary floor provides a hydrological barrier to the karst aquifer. The polje is covered with clayey and sandy deposits which are commonly up to $5 \mathrm{~m}$ thick, but near the eastern and northern rims, where the bedrock consists of limestone, depth of the sediment cover is 


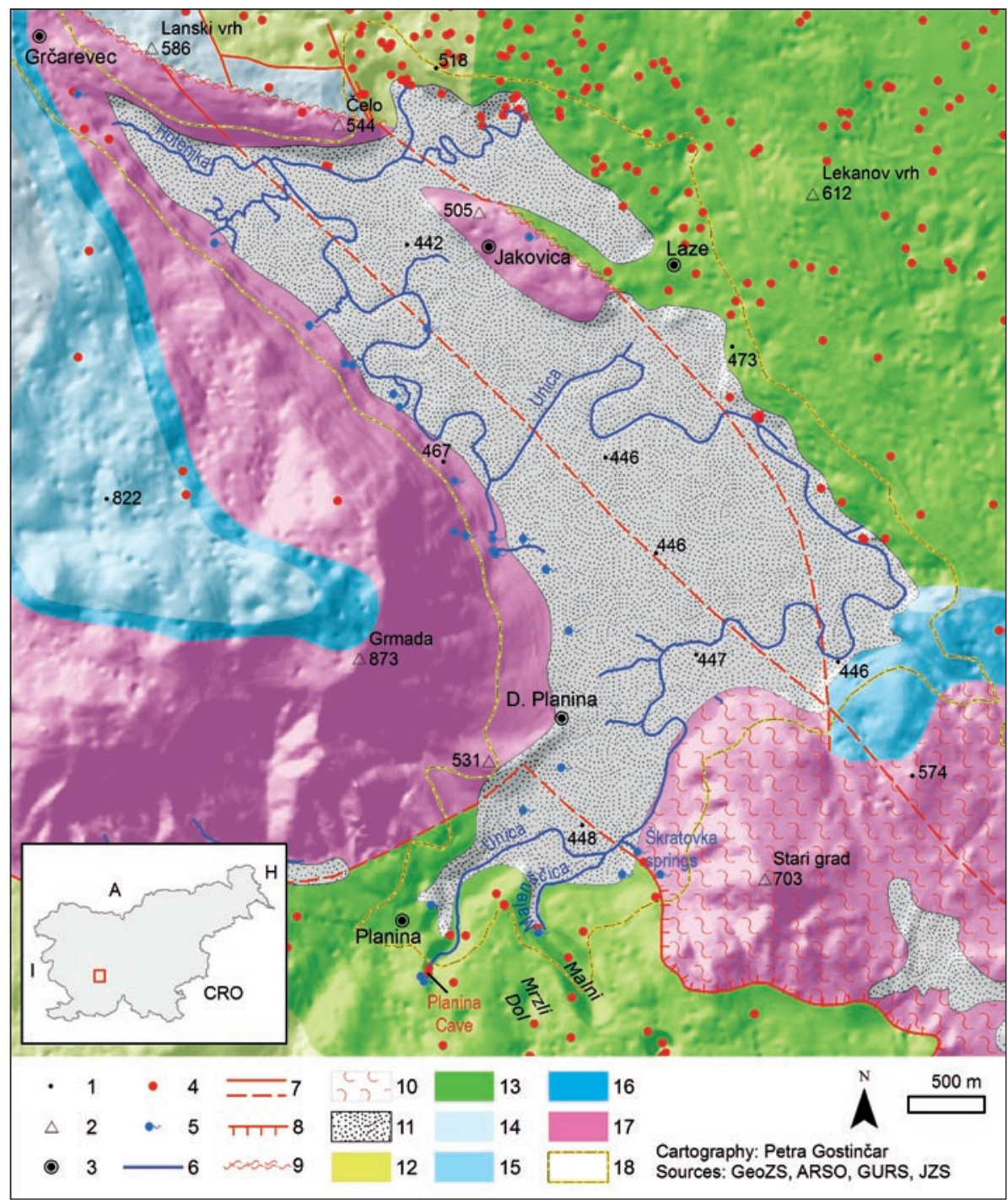

Fig. 1: Geological and hydrological characteristics of Planina Polje.

1. Elevation, 2. Peak, 3. Settlement, 4. Cave, 5. Source, 6. Surface flow, 7. Visible and covered fault, 8. Visible thrust, 9. Fault zone, 10. Milonite, 11. Quaternary, 12. Cretaceous limestone, 13. Jurassic limestone and dolomite, 14. Jurassic limestone, 15. Jurassic limestone and dolomite, 16. Jurassic dolomite, 17. Triassic dolomite, 18. Rim of the polje.

As floods appear regularly the Planina Polje can be classified as an overflow type of polje (Gams 1994). Permanent tributaries of the polje are the Unica River that flows out of the Planina Cave (Reg. No. 748) and the Malenščica River that has its spring in the Malni Pocket Valley. At higher discharges the rivers Škratovka in the south and Hotenjka in the northwest also flow to the polje. Hydrological characteristics of Planina Polje up to $25 \mathrm{~m}$. Grain-size of the deposits ranges from clay to sand (Ravnik 1976).

are strongly influenced by its geological characteristics. Karst springs and ponors on the polje appear mostly on
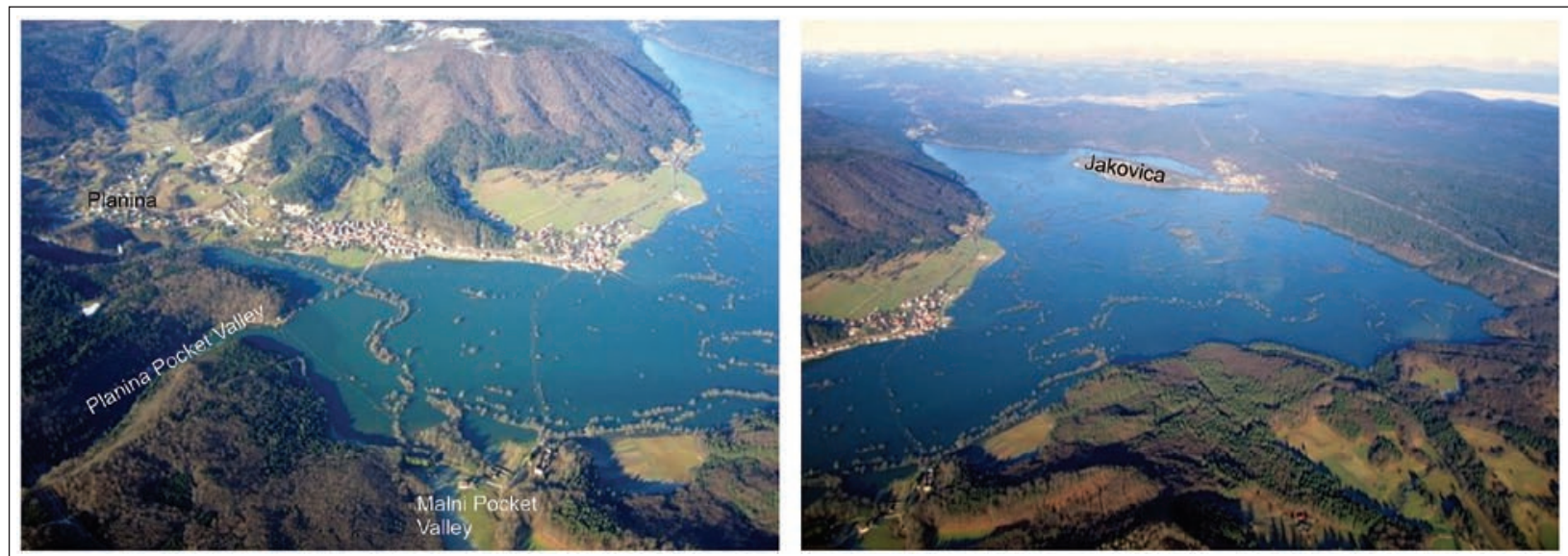

Fig. 2: Floods on Planina Polje (Photo: I. Marentič). 
Cretaceous limestone areas (the Malenščica River, the Unica River) or on the contact between Cretaceous limestone and Triassic dolomite (Škratovka) (Gospodarič \& Habič 1976).

The recorded inflow on the polje ranges between $1.4 \mathrm{~m}^{3} / \mathrm{s}$ and $130 \mathrm{~m}^{3} / \mathrm{s}$ and regularly exceeds the maximum outflow capacity of the ponors. This is why Planina Polje represents a storage basin for high flood waters. Floods occur when the discharge of the Unica River at the Hasberg gauging station exceeds $60 \mathrm{~m}^{3} / \mathrm{s}$ (Ravnik 1976). During floods, lasting on average 41 days per year (Gams 2004), the water level increases up to $8 \mathrm{~m}$ and reaches $450.2 \mathrm{~m}$ a.s.l. (Kovačič \& Ravbar 2011). The volume of water at that elevation calculated with DEM reaches approximately $59 \mathrm{Mm}^{3}$, with the lake surface area of $9.1 \mathrm{~km}^{2}$. However, the highest recorded floods reached the elevation of around $458 \mathrm{~m}$ a.s.l. (Gams 1979). The volume of the lake at this elevation was $136 \mathrm{Mm}^{3}$, with the lake surface area of $10.6 \mathrm{~km}^{2}$. According to the notes of W. Putick, the locals were reporting floods reaching as high as $464 \mathrm{~m}$ (Gams 1979), but it seems rather unlikely. The volume of the lake at this elevation would be about $202 \mathrm{Mm}^{3}$ with an area of $11.2 \mathrm{~km}^{2}$.

\section{TRACES OF HIGH FLOODS ON PLANINA POLJE}

Detailed investigations of Planina Polje and the cave systems of its inflow part (Fig. 3) have revealed numerous traces of floods which do not correspond with the level of known recent floods (Gospodarič 1976; Stepišnik 2010). These traces were identified in the surface and cave morphology and sediments. Patches of allochtoneous loamy deposits can be found on some parts of the surface and in the caves.

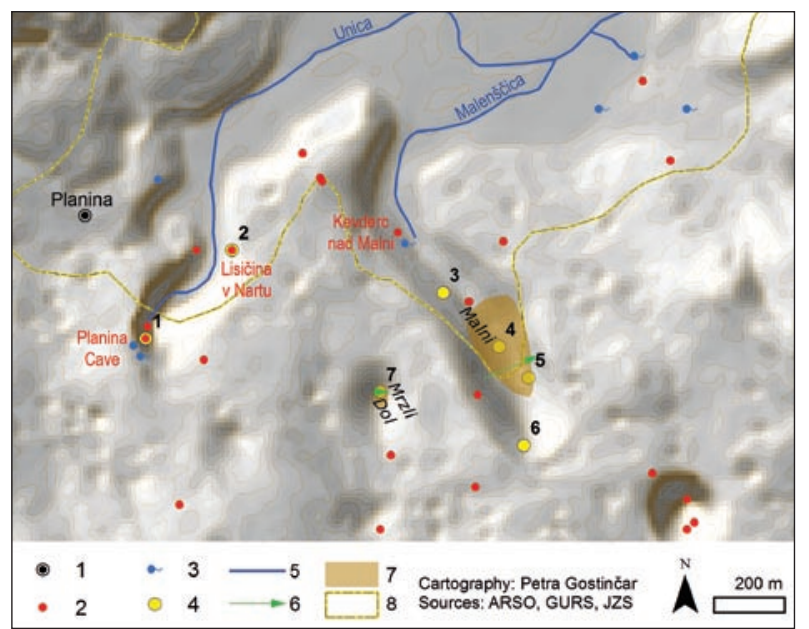

Fig. 3: Inflow part of Planina Polje.

1. Settlement, 2. Cave, 3. Karst spring, 4. Sampling point (1Planinska jama, 2 - Lisičina v Nartu, 3-6 - Malni, 7 - Mrzli Dol), 5. Surface flow, 6. ERI profile location, 7. Loamy deposits, 8. Rim of the polje.

\section{MALNI POCKET VALLEY}

The Malni Pocket Valley is situated on the southern part of the polje. The pocket valley is $1.1 \mathrm{~km}$ long and, on average, about $250 \mathrm{~m}$ wide. The rim of the pocket valley is
$55 \mathrm{~m}$ high in the northern outflow side and $120 \mathrm{~m}$ high in the southern part. The floor in the southern part of the pocket valley lies at the elevation of about $500 \mathrm{~m}$ a.s.l. and it gradually lowers towards Planina Polje in the north. The springs of the Malenščica River, a tributary of the Unica River on Planina Polje, are situated in the middle part of the pocket valley. The discharge of the Malenščica River varies between 1.1 to $9.9 \mathrm{~m}^{3} / \mathrm{s}$ (Kolbezen \& Pristov 1998).

The upper part of Malni Pocket Valley is filled with loamy sediment up to $490 \mathrm{~m}$ a.s.l. The sediment covers $0.05 \mathrm{~km}^{2}$ and is deposited over limestone rubble which is believed to be a result of intensive mechanical weathering during ice ages (Gams 1966). Grain-size analysis of the sediment revealed that the loam consists mainly of clay loam particles (Fig. 7). Petrographic analysis of sandy fractions of the sediment revealed flysch-derived particles of chert, limonite, quartz sandstone and mica.

The results of ERI of the cross-section in the upper part of the Malni Pocket Valley has shown that its bedrock slopes, with resistivity values higher than 1,000 ohm-m (Fig. 4; red and orange colour), are covered with scree or weathered bedrock with resistivity values between 150 and 1,000 ohm-m (Fig. 4; yellow and green colour). The floor is entirely filled with less resistant loamy sediment with resistivity values up to $150 \mathrm{ohm}-\mathrm{m}$ (Fig. 4; blue colour) (Stepišnik \& Mihevc 2008). Thickness of the loamy material exceeds $22 \mathrm{~m}$.

\section{COLLAPSE DOLINE MRZLI DOL}

Mrzli Dol is a collapse doline situated $200 \mathrm{~m}$ west of Malni Pocket Valley and about $500 \mathrm{~m}$ north of the passages of the Planina Cave. The longer diameter of Mrzli Dol is $224 \mathrm{~m}$, the shorter diameter is $218 \mathrm{~m}$ and the average depth is $46 \mathrm{~m}$. Approximate volume of the collapse do- 
line is $0.8 \mathrm{Mm}^{3}$. The slopes are covered with scree and a thin layer of soil. The floor is flattened with loamy sediment at $494 \mathrm{~m}$ a.s.l. where the average diameter is about 15 m (Stepišnik 2010).

The fine-grained sediment fill forming the flat floor of the collapse doline was examined. Grain-size analysis of the sediment revealed that the loam consists of silty clay particles (Fig. 7). Petrographic analysis of the loam revealed flysch-derived minerals of mica, quartz, sand and chert.

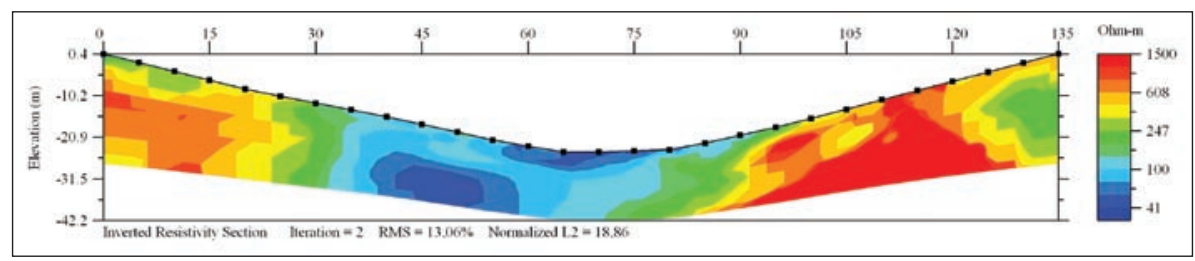

Fig. 4: ERI profile of Malni Pocket Valley.

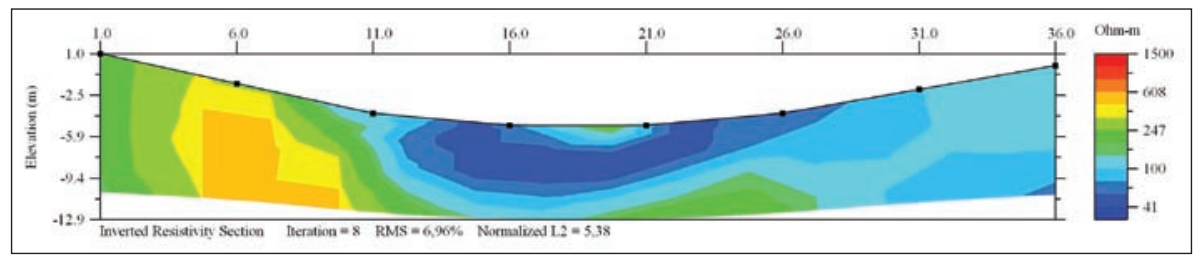

Fig. 5: ERI profile of the collapse doline Mrzli Dol floor.

Results of ERI have shown that the floor of the collapse doline is filled with less resistant (up to $150 \mathrm{ohm}-\mathrm{m}$ ) loamy sediment (Fig. 5; blue colour), overlying scree footslope of the collapse doline with resistivity values higher than $150 \mathrm{ohm}-\mathrm{m}$ (Fig. 5; yellow and green colour) (Stepišnik \& Mihevc 2008). Thickness of the loamy sediment is about $8 \mathrm{~m}$.

\section{THE PLANINA CAVE}

The Planina Cave is situateds in the southwestern part of Planina Polje, with its entrance under a $50 \mathrm{~m}$ high wall at the end of a 1,200 $\mathrm{m}$ long pocket valley. The entrance lies on the elevation of $453 \mathrm{~m}$ a.s.l. and the inner parts of the cave are at a slightly higher elevation. The Planina Cave is a horizontal epiphreatic cave that discharges the main spring of the Unica River. The total discharge varies between 1.1 and $100 \mathrm{~m}^{3} / \mathrm{s}$, whereas the mean discharge is $21 \mathrm{~m}^{3} / \mathrm{s}$ (Frantar 2008). The cave is $6,656 \mathrm{~m}$ long with hydrologically active passages. Only some small side passages at higher elevations are inactive. These inactive passages are about $15 \mathrm{~m}$ wide and $15 \mathrm{~m}$ high (Cave Register of JZS 2011). The Planina Cave is the longest and the largest cave of the inflow part of the Planina Polje.

The Planina Cave is filled with various sediments, mostly limestone gravel, chert gravel and laminar clay.
The mineral composition of the deposits indicates that the waters depositing the clastic load in the cave must have flown from the Pivka Basin where Eocene flysch rocks prevail. In addition, the cave is partly filled with limestone gravel, which according to Gospodarič (1976) originated from the collapse doline Planinska Koliševka. Gospodarič (1976) described sediments from the Planina Cave in the following stratigraphic succession: the oldest are coloured chert gravels and older laminated loam (Middle Quaternary), white chert gravel (Riss), flowstone (Riss-Würm), younger laminated loam (Lower Würm), flowstone (Middle Würm), flood loam (Upper Würm), flowstone (Postglacial) and the youngest flowstone (Holocene). Nevertheless, loam deposits which, according to Gospodarič, are of flood origin, are situated at the elevation around $495 \mathrm{~m}$ a.s.l. above all other stages of sedimentation in the cave. Furthermore, it is also situated above the limestone rubble from Planinska Koliševka which was dated to the upper Würm (Gospodarič 1976). Paleomagnetic dating in the Planina Cave (Zupan Hajna et al. 2008) showed that all sediments sampled in the side passage Rudolfov Rov (at cca. $460-475 \mathrm{~m}$ a.s.l.), have normal polarization. The sediments were thus considered to be younger than $0.73 \mathrm{Ma}$ and in addition, suggesting that the results are in good accordance with Mindel age (0.35-0.59 Ma) proposed by Gospodarič (1981) (Zupan Hajna et al. 2008).

Patches of loamy sediment overlie other sediments in the entire cave at the elevations between 470 and $495 \mathrm{~m}$ a.s.l. (Gospodarič 1976). In the hydrologically active channels, the loamy sediment is mostly absent, while it is well-preserved along the whole length of some inactive side passages. In side passages Katernov Rov, Paradiž and Tiha Jama the flood loam reaches the elevation of $495 \mathrm{~m}$ a.s.l. The highest loam deposits were also mentioned by Gospodarič (1976) who concluded that these sediments could be a result of higher floods in the underground. However, Gospodarič did not study the floods in detail and did not associate underground floods to flooding of the polje.

Tiha Jama is a small side passage of the Planina Cave. The deposits of loamy sediment are covering the passage floor up to the elevation of $495 \mathrm{~m}$ a.s.l. The sediment consists of thin stratigraphic layers with a thickness 


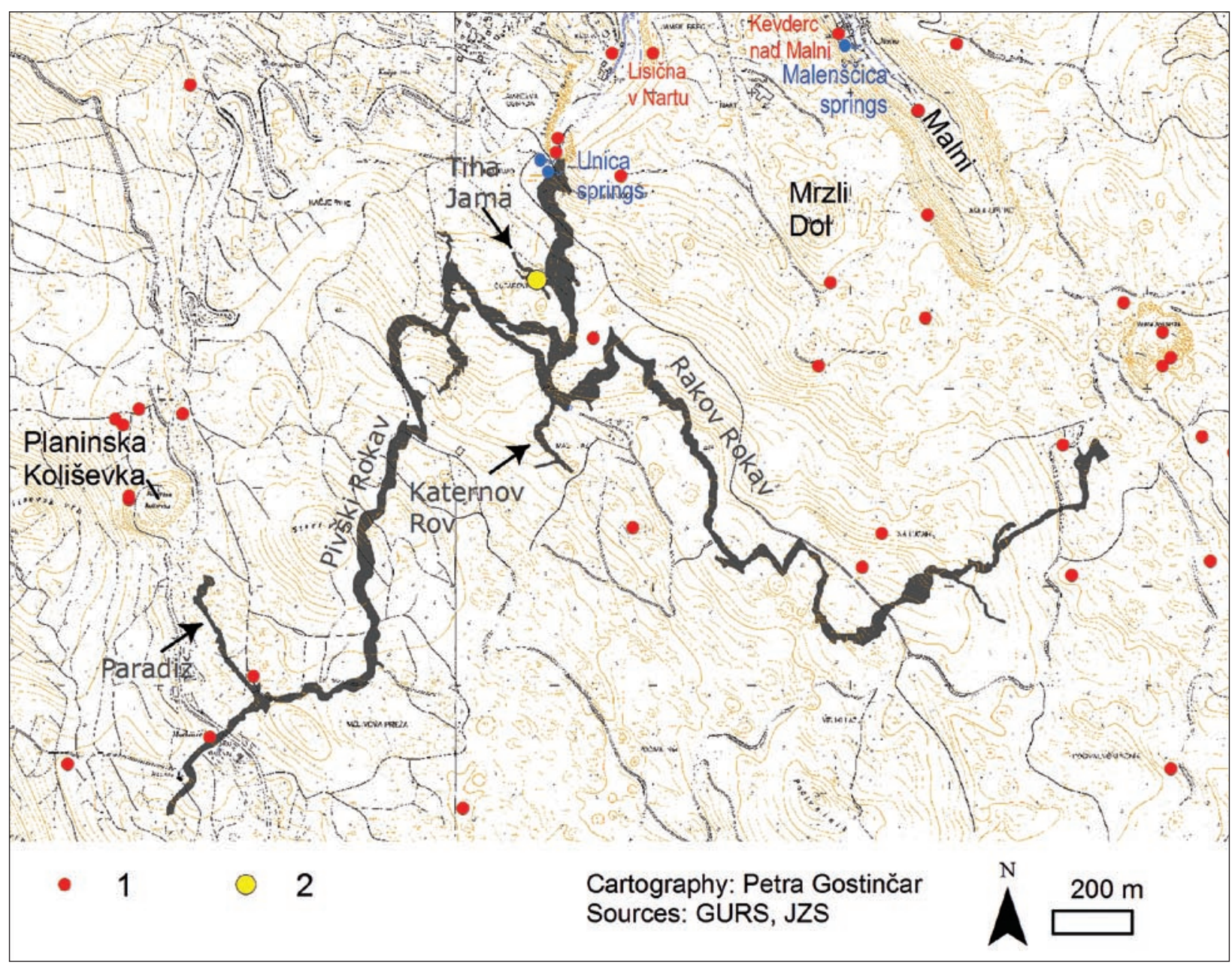

Fig. 6: Ground plan of Planina Cave.

1. Cave entrances of surrounding caves, 2. Sampling point.

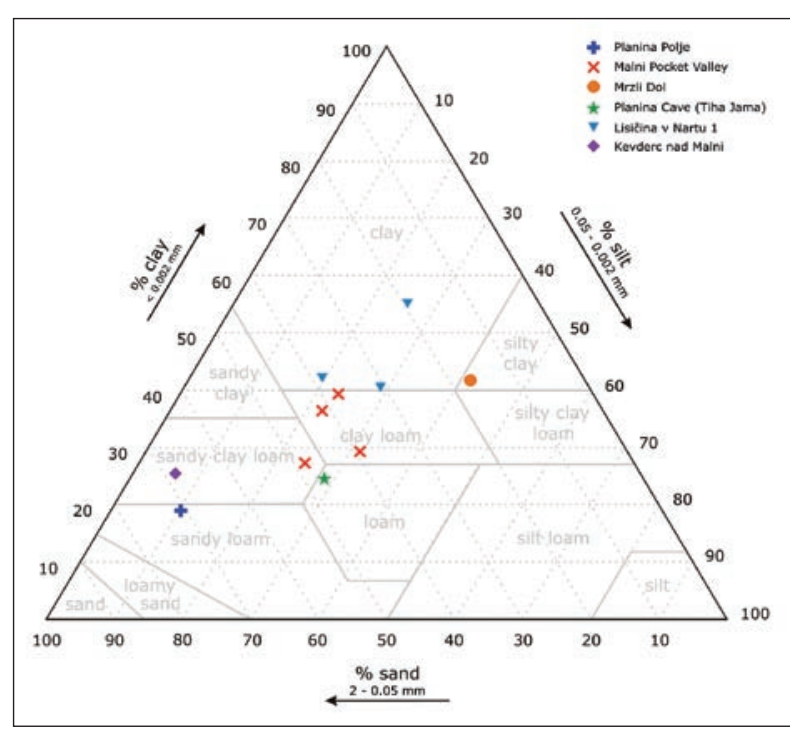

Fig. 7: Texture triangle with results of grain-size analysis of sediment samples. up to $1 \mathrm{~cm}$. Grain-size of the sediment is of loam particles (Fig. 7). Petrographicaly it consists of flysch-derived particles of chert, quartz sandstone and mica.

In Tiha Jama a part of a flowstone on the elevation about $495 \mathrm{~m}$ a.s.l. was dated using the Radiocarbon $\left({ }^{14} \mathrm{C}\right)$ dating method. The layer of flowstone was located between the upper layers of the loamy sediment which were deposited from the last few flood phases. The dating analysis with ${ }^{14} \mathrm{C}$ has shown an absolute age of 5,706 \pm 49 years BP.

\section{OTHER CAVES IN THE HINTERLAND OF THE INFLOW PART OF PLANINA POLJE}

On the inflow part of the Planina Polje also 15 smaller caves are known. They are mostly positioned between the Malni Pocket Valley and the Planina Cave (Fig. 3). Most of the caves are vadose shafts with fragments of epiphreatic caves. Well preserved loamy fills in the caves Lisičina $\mathrm{v}$ Nartu (Reg. No. 2892) and Kevderc nad Malni (Reg. No. 2914) were investigated (Cave Register JZS 2011). 
The cave Lisičina $\mathrm{v}$ Nartu is situated on the right bank of the Unica River at $480 \mathrm{~m}$ a.s.l., which is about $32 \mathrm{~m}$ above the local polje floor. The cave is about $80 \mathrm{~m}$ long and mostly horizontal. Loamy sediments are to be found on several locations, but samples of the loamy sediment were taken from the highest preserved location at $485 \mathrm{~m}$ a.s.l. The grain-size analysis has shown that the sediment contains clay particles (Fig. 7). The petrographic analysis of the sediment has revealed that it consists of flysch-derived mica and chert minerals.
The cave Kevderc nad Malni is situated on the western slope of the Malni Pocket Valley. The entrance to this horizontal cave is at $466 \mathrm{~m}$ a.s.l., which is $18 \mathrm{~m}$ above the polje's floor. The floor of the $15 \mathrm{~m}$ long cave is mostly covered with limestone rubble though in several parts small patches of loamy sediment are preserved. Grainsize analysis has revealed that the sediment contains sandy clay and loam particles (Fig. 7). Petrographic analysis revealed that the sediment consists of flysch-derived chert, quartz sandstone and mica.

\section{DISCUSSION}

Loamy deposits on the surface and in the caves of the inflow part of Planina Polje have grain-size of clayey loam, clay, sandy clay loam and loam. Petrographic composition of the sediment is very similar to recent sediments of the Unica River on the polje. This sediment consists particularly of quartz, quartz sandstone, chert and mica minerals which are allogenic minerals mostly derived from flysch Pivka Basin. Grain-size and petrographic properties together point out that loamy material is not of local origin but it is allogenic material which was deposited from a stagnant water body. Meaning, the sediment is a flood loam which was deposited during flood events in various areas of inflow part of the polje in the same manner as it is deposited in lower elevations during recent floods.

The flood loam is present as much as $37 \mathrm{~m}$ higher than the highest elevation of floods in known hydrological conditions. The highest elevation of the flood loam on the surface as well as in the caves is quite uniform and is about 490 to $495 \mathrm{~m}$ a.s.l., what indicates that the piezometric level in the karst reached this elevation. The high water level was not limited to the subsurface but also to the area of the Planina Polje. The depth of the lake on the polje was approximately $50 \mathrm{~m}$, with a volume of $601 \mathrm{Mm}^{3}$ and a surface area of $14.8 \mathrm{~km}^{2}$.

The thickness of the flood loam varies from more than $22 \mathrm{~m}$ in the Malni Pocket Valley to $8 \mathrm{~m}$ in the collapse doline Mrzli Dol. Depths of the flood loam fills in the caves were not established, however, it exceeds a couple of meters. Flood loam consists of multiple layers which were deposited in different flood events. Each reemerging of the lake resulted in another thin flood loam layer.

The age of the flood loam deposition can be interpreted in various ways. In the Malni Pocket Valley the flood loam is covering a scree which was defined by Gams (1966) as Würmian cryoclastic material. So the flood loam must have been deposited in the Holocene.

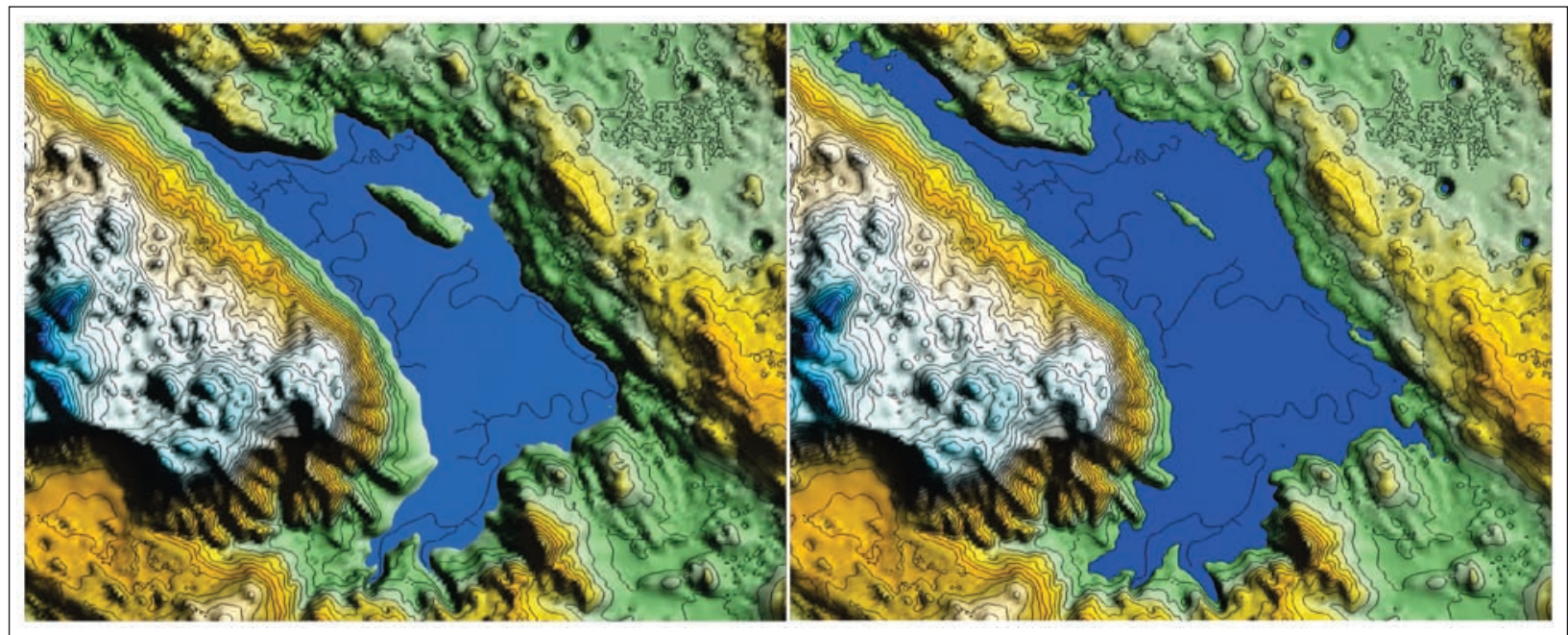

Fig. 8: Extent of present (left) and early Holocene (right) floods on the Planina Polje. 
Gospodarič (1976) established that the older cave sediments, which are covered by the flood loam, are of Upper Würm age but none of these interpretations were defined by numerical dating.

The time frame of the flood occurrence was defined within this research by radiocarbon dating of a flowstone layer from side passage Tiha Jama in the Planina Cave. The result revealed that the last phase of the flooding was at 5,706 $\pm 49 \mathrm{BP}$. The time frame of the flood roughly corresponds with the Altithermal $(8,000-5,000 \mathrm{BP})$ - the Holocene climatic optimum, sometimes also called Holocene "wet phase" (Bubenzer \& Riemer 2007). The temperatures in the Altithermal reached the highest values in the Holocene and they were by 2 to $4^{\circ} \mathrm{C}$ higher than the present ones (Ogrin 2005).Holocene climate variability has also been investigated on the base of lake-level fluc- tuations. For example, in the Jura Mountains, the northern French Pre-Alps and the Swiss Plateau throughout the Holocene 15 phases of higher lake-level had appeared (Magny 2004). Lake level evidence (Yu \& Harrison 1995) suggest that the mid-Holocene climate across the northern Mediterranean region was moister than the present climate. This is one of the possible causes of Planina Polje high floods. Another reason for high floods could have also been a smaller capacity of the outflow due to filling of ponors with various deposits.

The Planina Polje is the lowest karst poljes in Ljubljanica catchment. The flooding of Planina Polje might as well be a result of some local hydrologic conditions elsewhere in the watershed. The evidences of these different hydrological characteristic in the past have not been systematically studied yet.

\section{CONCLUSIONS}

In the inflow part of Planina Polje flood loam was deposited on the surface and in the caves to the elevations up to $495 \mathrm{~m}$ a.s.l. Those sediments indicate an extent and height of the past floods in the area. The highest elevation of the sediments suggests that the floor of the polje was approximately $50 \mathrm{~m}$ below the water level.

The time of the floods was determined to $5,706 \pm 49$ BP which corresponds with climatically wetter Altithermal and the transition between Mesolithic and Neolithic in the area. So, repetitive extreme floods can be a result of solely higher precipitation in favourable climatic conditions but they can also be a result of land use change which was significantly altered roughly at that time. A possible trigger of floods can also be a decrease of the polje outflow capacity. Filling of ponors with allogenic materials or wood debris can significantly influence their efficiency. Especially the effect of wood debris combined with layers of allogenic material influencing the outflow capacity should be studied in detail as the last occurrence of high floods generally corresponds with beginning of the cultivation of land and removal of natural forest from the poljes.

Existence and approximate time frame of the flood occurrence was defined in the article. However, on the other hand explanations of causes of the high floods are merely speculations. Therefore future investigations must be oriented in more detailed age estimation and comparison with climatic conditions afterward. If it is found that higher temperature and precipitation rates are initiating extreme floods we should consider the possible impact of their reoccurrence in the present climate changes.

\section{REFERENCES}

Bubenzer, O. \& H. Riemer, 2007: Holocene Climatic Change and Human Settlement Between the Central Sahara and the Nile Valley: Archaeological and Geomorphological Results.- Geoarchaeology: An International Journal, 22, 607-620.

Buser, S., Grad, K. \& M. Pleničar, 1970: Tolmač za list Postojna.- Zvezni geološki zavod, pp. 62, Beograd.
Cave Register of Speleological Association of Slovenia (JZS). 2011. Ljubljana, Speleological Association of Slovenia.

Frantar, P. (ed.), 2008: Water balance of Slovenia 19712000.- Ministrstvo za okolje in prostor, Agencija Republike Slovenije za okolje, pp. 119, Ljubljana. 
Gams, I., 1966: K hidrologiji ozemlja med Postojnskim, Planinskim in Cerkniškim poljem.- Acta Carsologica, 4, 7-54.

Gams, I., 1979: Raziskovanje poplavnih področij v Sloveniji. Poplave na Planinskem polju.- SAZU GIAM, pp. 26, Ljubljana.

Gams, I., 1994: Types of the poljes in Slovenia, their inundations and land use.- Acta Carsologica, 23, 286-302.

Gams, I., 2004: Kras v Sloveniji v prostoru in času.- Založba ZRC, pp. 515, Ljubljana.

Geological Survey of Slovenia (GeoZS), 2003: Geological map of SFRY, Postojna (digital map). 1 : 100,000.Ljubljana.

Gospodarič, R. \& P. Habič, 1976: Underground water tracing; investigations in Slovenia 1972-1975.- IZRK SAZU, pp. 309, Postojna.

Gospodarič, R., 1976: Razvoj jam med Pivško kotlino in Planinskim poljem v kvartarju.- Acta Carsologica, 7, 9-139.

Gospodarič, R., 1981: Generations of speleothems in the Classical Karst of Slovenia.- Acta Carsologica, 9, 90-110.

Kolbezen, M. \& J. Pristov, 1998: Površinski vodotoki in vodna bilanca Slovenije.- Ministrstvo za okolje in prostor, Hidrometeorološki zavod Republike Slovenije, pp. 98, Ljubljana.

Kovačič, G. \& N. Ravbar, 2011: Dinamika poplavljanja Planinskega polja v obdobju oktober 2008-april 2009.- Naravne nesreče - Neodgovorna odgovornost, 2, 91-101.

Magny, M., 2004: Holocene climate variability as reflectedby mid-European lake-level fluctuations and its probable impact on prehistoric human settlements.Quaternary International, 113, 65-79.

Ogrin, D., 2005: Spreminjanje podnebja v holocenu.Geografski vestnik, 77, 1, 57-66.

Ravnik, D., 1976: Kameninska podlaga Planinskega polja.- Geologija, 19, 291-315.
Slovenian Environment Agency (ARSO): Watercourses and springs in Slovenia (digital database).

Stepišnik, U. \& A. Mihevc, 2008: Investigatoin of structure of various surface karst formations in limestone and dolomite bedrock with application of the electrical resistivity imaging.- Acta Carsologica, 37, 1, 133-140.

Stepišnik, U., 2010: Udornice v Sloveniji.- Znanstvena založba Filozofske fakultete, E-Geograff 1, pp. 118, Ljubljana.

Surveying and Mapping authority of Republic of Slovenia (GURS): Digital Elevation model 12,5 $x$ 12,5 m.Ljubljana

Surveying and Mapping authority of Republic of Slovenia (GURS): Topographic Map, D 22 34. 1:5,000.Ljubljana.

Surveying and Mapping authority of Republic of Slovenia (GURS): Topographic Map, D 22 35. 1:5,000. Ljubljana.

Vrabec, M., 1994: Some thoughts on the pull-apart origin of karst poljes along the Idrija strike-slip fault zone in Slovenia.- Acta Carsologica, 23, 158-168.

Yu, G. \& S.P. Harrison, 1995: Lake status records from Europe: Data base documentation.- pp. 451, Lund.

Zupan Hajna, N., Mihevc, A., Pruner, P. \& P. Bosák, 2008: Paleomagnetism and magnetostratigraphy of karst sediments in Slovenia.- Založba ZRC, pp. 266, Ljubljana-Postojna.

Žibrik, K., Lewicki, F. \& A. Pičinin, 1976: Hydrologic investigations. Investigations in Ljubljanica river basin, Investigations before the tracing test 1972-1975.- In: Gospodarič, R. \& P. Habič (eds.) Underground water tracing: Investigations in Slovenia 1972-1975, Third International Symposium of Underground Water Tracing (3. SUWT), Ljubljana-Bled. IZRK SAZU, 43-56, Postojna 